Tropical Journal of Pharmaceutical Research May 2019; 18 (5): 1149

ISSN: $1596-5996$ (print); 1596-9827 (electronic)

(C) Pharmacotherapy Group, Faculty of Pharmacy, University of Benin, Benin City, 300001 Nigeria.

All rights reserved.

Available online at http://www.tjpr.org

http://dx.doi.org/10.4314/tjpr.v18i5.33

\title{
Erratum for "Effect of aqueous leaf extract of Thunbergia laurifolia on alcohol-induced liver injury in rats"
}

\author{
Sarawoot Palipoch ${ }^{1 *}$ Phanit Koomhin', Chuchard Punsawad1, Prasit \\ Suwannalert ${ }^{2}$
}

${ }^{1}$ School of Medicine, Walailak University, 222 Thaiburi, Thasala District, Nakhon Si Thammarat, 80161, ${ }^{2}$ Department of Pathobiology, Faculty of Science, Mahidol University, 272 Rama VI Road, Ratchathewi District, Bangkok 10400, Thailand

*For correspondence: Email: spalipoch@hotmail.com, sarawoot.pa@wu.ac.th; Tel: +66 7567 2873; Fax: +66 75672807

\section{Erratum}

Palipoch et al Trop J Pharm Res 2019, 18(4): 823-828 http://dx.doi.org/10.4314/tjpr.v18i4.20

A wrong abstract was inadvertently published in the above article. This error is highly regretted. The correct abstract is published below.

\section{Abstract}

Purpose: To investigate the antioxidant and anti-inflammatory effects of aqueous leaf extract of $T$. laurifolia against alcoholic liver injury in rats.

Methods: Male Wistar rats were administered either normal saline, ethanol $(E t O H)$, normal saline with low or high dose $T$. laurifolia leaf extract (TL-LD or TL-HD), EtOH with TL-LD or EtOH with TL-HD. Blood biochemical indices: hepatic malondialdehyde (MDA) levels, liver histopathology, hepatic cytochrome P450 2E1 (CYP2E1), nicotinamide adenine dinucleotide phosphate (NADPH) oxidase, and proinflammatory cytokines, including interleukin 1 beta (IL-1 $\beta$ ) and tumor necrotic factor alpha (TNF- $\alpha)$ mRNA expressions, were determined using standard methods.

Results: The leaf extract of T. Laurifolia decreased hepatic MDA levels, improved liver pathology and down-regulated mRNA expressions of CYP2E1, NADPH oxidase and pro-inflammatory cytokinesin ethanol-treated rats.

Conclusion: These results demonstrate that aqueous extract of $T$. Laurifolia exerts hepatoprotective effect against alcoholic liver injury through a mechanism involving inhibition of oxidative stress and inflammation.

Keywords: Thunbergia laurifolia, Alcohol, Liver injury, Oxidative stress, inflammation, Protection

Citation: Palipoch S, Koomhin P, Punsawad C, Suwannalert $P$. Effect of aqueous leaf extract of Thunbergia laurifolia on alcohol-induced liver injury in rats. Trop J Pharm Res 2019; 18(4):823-828 Erratum: 2019; 18(5):911-912 http://dx.doi.org/10.4314/tjpr.v18i5.33

Tropical Journal of Pharmaceutical Research is indexed by Science Citation Index (SciSearch), Scopus, International Pharmaceutical Abstract, Chemical Abstracts, Embase, Index Copernicus, EBSCO, African Index Medicus, JournalSeek, Journal Citation Reports/Science Edition, Directory of Open Access Journals (DOAJ), African Journal Online, Bioline International, Open-J-Gate and Pharmacy Abstracts 